Check for updates

Cite this: RSC Adv., 2022, 12, 5173

Received 22nd November 2021 Accepted 4th February 2022

DOI: $10.1039 / \mathrm{d} 1 \mathrm{ra0} 8555 \mathrm{~g}$

rsc.li/rsc-advances

\section{What are the prospects for using complexes of copper(II) and zinc(II) to suppress the vital activity of Mycolicibacterium smegmatis? $\uparrow$}

\author{
Irina A. Lutsenko, (D)*a Dmitry E. Baravikov, (D) ab Kseniya A. Koshenskova, ab \\ Mikhail A. Kiskin, ${ }^{a}$ Yulia V. Nelyubina, ${ }^{C}$ Petr V. Primakov, ${ }^{C}$ Yulia K. Voronina, (D)a \\ Veronika V. Garaeva, ${ }^{\text {ce }}$ Dmytry A. Aleshin, ${ }^{c}$ Teimur M. Aliev, (D) ${ }^{c}$ Valery N. Danilenko, ${ }^{d}$ \\ Olga B. Bekker ${ }^{d}$ and Igor L. Eremenko (iD) ${ }^{a}$
}

\begin{abstract}
New complexes of zinc(II) and copper(II) with 2-furoic acid (Hfur), acetic acids and $\mathrm{N}$-donor ligands with the compositions $\left[\mathrm{Zn}_{2}(\text { fur })_{4}\right]_{n}$ (1), $\left[\mathrm{Zn}_{2}(\text { fur })_{4}\left(\mathrm{NH}_{2} \mathrm{py}\right)_{2}\right]$ (2, $\mathrm{NH}_{2}$ py = 3-aminopyridine), [Zn(fur) $)_{2}($ neoc) $)$ (3, neoc $=$ 2,9-dimethyl-1,10-phenantroline), $\left[\mathrm{Zn}(\mathrm{OAc})_{2}(\right.$ neoc) $]\left(4, \mathrm{OAc}=\right.$ acetat-anion), and $\left[\mathrm{Cu}(\mathrm{fur})_{2}(\mathrm{neoc})\left(\mathrm{H}_{2} \mathrm{O}\right)\right](5)$ were synthesized. The structures of the compounds were established by single crystal $\mathrm{X}$-ray diffraction analysis. Complexes 1 and 2 are binuclear; whereas 3-5 are mononuclear. The stabilization of supramolecular architectures in crystals for compounds 1-5 occurs due to $\pi-\pi$-bonding between heterocycles and hydrogen interactions that provide good solubility in aqueous solutions. The stability of the complexes upon dissolution in $5 \%$ dextrose and $0.9 \% \mathrm{NaCl}$ was confirmed by UV-vis spectroscopic and NMR $\left({ }^{1} \mathrm{H}\right)$ data. The study of in vitro biological activity was carried out against the non-pathogenic strain of Mycolicibacterium smegmatis that is a model for M. tuberculosis. The synergistic effect of ligands is observed for complexes $3-5$ and is characterized by an increase in the biological activity values. On passage from $\mathrm{Zn}^{2+}$ to $\mathrm{Cu}^{2+}$ complexes, the biological activity increases and the maximum effect is observed for compound [Cu(fur) $)_{2}($ phen)]. Analysis of the transcriptomic profiles of the $M$. smegmatis $m c^{2} 155$ strain under the pressure of the copper complex [Cu(fur) 2 (phen)] made it possible to isolate 185 genes, one quarter of which are associated with the compensation of iron deficiency in the bacterial strain. Genes associated with the transport and metabolism of heavy metals, biosynthesis of fatty and amino acids, biodegradation and transport of urea were also isolated.
\end{abstract}

\section{Introduction}

Tuberculosis is among the most hazardous diseases of mankind (according to the WHO) and takes the lives of tens of thousands of people every year. ${ }^{1}$ More than 130 years have passed since the discovery of the tuberculosis pathogen by R. Koch (1882) - Koch's

${ }^{a}$ N.S. Kurnakov Institute of General and Inorganic Chemistry of the Russian Academy of Sciences, Leninsky prosp. 31, 119991 GSP-1, Moscow, Russian Federation. E-mail: irinalu05@rambler.ru; Fax:+7-495-952-1279

${ }^{b}$ D.I. Mendeleev University of Chemical Technology of Russia, M. Pirogovskaya str. 1a, 119435 Moscow, Russian Federation

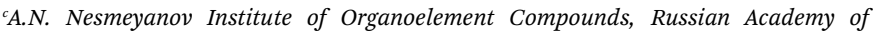
Sciences, Vavilova str. 28, 119991 Moscow, Russian Federation

${ }^{d}$ Vavilov Institute of General Genetics, Russian Academy of Sciences, Gubkina, 311933 Moscow, Russian Federation

${ }^{e}$ Moscow Institute of Physics and Technology, 9 Institutskiy per, Dolgoprudny, Moscow Region, 141701, Russian Federation

$\dagger$ Electronic supplementary information (ESI) available. CCDC 2112367 (1), 2112368 (2), 2112369 (3), 2112370 (4) and 2115090 (5). For ESI and crystallographic data in CIF or other electronic format see DOI: 10.1039/d1ra08555g bacillus - but doctors, biologists and biochemists still have not been able to definitively conquer this infection. The problem lies in the fast development of various types of resistance by mycobacteria which currently count more than a dozen, namely, drug resistance, multidrug resistance (MDR), HIV-associated varieties of tuberculosis, latent, dormant, multi-resistant and other species that cause global problems in the treatment of this disease. ${ }^{2-6}$ Creating drugs for the chemotherapy of tuberculosis is among the fundamental constituents of modern medicine. Obviously, the problem of searching for compounds with new mechanisms of action comes to the fore. Perhaps, coordination compounds with essential (vital) metals (Cu, Zn, Co, Fe, $\mathrm{Mg}$ etc.) might provide a solution. For example, this approach already proved efficient in the treatment of cancer, malaria, toxoplasmosis, and other hazardous diseases (cisplatin, auranofin, carboplatin, nitroprusside, silver sulfadiazine, etc.). ${ }^{7-23}$ Today there are no anti-tuberculosis drugs based on coordination compounds in medicine. Apparently, the development of such drugs is hindered by the insufficient understanding of the role of metal ions in the physiology and homeostasis of mycobacteria. Nevertheless, work in this direction is underway, as shown by an 
exponential increase in the number of publications proving the efficiency of complexes in suppressing the vital activity of mycobacteria and other pathogens. ${ }^{24-29}$ 2-Furoic acid (pyromucic acid, Hfur) was taken as the organic ligand to create complexes with anti-tuberculosis activity. The furan core of this compound is an ancestor of a group of antimicrobial drugs such as furazolidone, furadonin, enterofuril, etc. Earlier, S. Melnic et al. ${ }^{\mathbf{3 0}}$ showed that heterometallic triangular $\left\{\mathrm{Fe}_{2} \mathrm{CoO}\right\}$ complexes with fur $^{-}$anions exhibited in vitro activity against Mycobacterium tuberculosis $\mathrm{H} 37 \mathrm{Rv}$. Of the compounds with the composition $\left.\left[\mathrm{Fe}_{2} \mathrm{MO} \text { (fur }\right)_{6} \mathrm{~L}\right]$ studied $\left(\mathrm{M}=\mathrm{Mn}^{2+}, \mathrm{Co}^{2+}, \mathrm{Ni}^{2+} ; \mathrm{L}=\mathrm{H}_{2} \mathrm{O}\right.$, THF, 3Cl$\mathrm{Py})$, the $\left[\mathrm{Fe}_{2} \mathrm{Co}(\mathrm{O})(\text { fur })_{6}(\mathrm{THF})\left(\mathrm{H}_{2} \mathrm{O}\right)_{2}\right]$ heteronuclear complex was found to have in vitro biological activity against $M$. tuberculosis H37Rv. Further studies of furoate complexes with various cations $\left(\mathrm{Ni}^{2+}, \mathrm{Fe}^{3+}, \mathrm{Co}^{2+/ 3+}, \mathrm{Zn}^{2+}, \mathrm{Cu}^{2+}\right)$ showed that the mycobacterium was most sensitive to $\mathrm{Zn}^{2+}$ and $\mathrm{Cu}^{2+} \cdot{ }^{30-35}$ In continuation of the "structure activity relationship (SAR)" studies, Zn(II) complexes were synthesized, namely, polymeric $\left[\mathrm{Zn}_{2}(\text { fur })_{4}\right]_{n}$ (1), bi- $\left[\mathrm{Zn}_{2}(-\right.$ fur $\left.)_{4}\left(\mathrm{NH}_{2} \mathrm{py}\right)_{2}\right]\left(2, \mathrm{NH}_{2}\right.$ py $=3$-aminopyridine $)$ and mononuclear [Zn(fur $)_{2}$ (neoc)] (3, neoc $=$ 2,9-dimethyl-1,10-phenantroline), $\left[\mathrm{Zn}(\mathrm{OAc})_{2}(\right.$ neoc) $\left.)\right](4)$ and $\left[\mathrm{Cu}(\text { fur })_{2}(\right.$ neoc $\left.)\left(\mathrm{H}_{2} \mathrm{O}\right)\right](5)$. The structures of all the compounds obtained were resolved by direct single-crystal X-ray diffraction analysis. The stability of complexes 1-5 was confirmed by UV-vis spectroscopy upon dissolution in physiological $0.9 \% \mathrm{NaCl}$ and $5 \%$ glucose solutions. The stability of compound 3 was studied by the NMR $\left({ }^{1} \mathrm{H}\right)$ method in a DMSO solution. The biological activity of 1-5 in vitro was determined against non-pathogenic Mycolicibacterium smegmatis (a model for M. tuberculosis $\mathrm{H} 37 \mathrm{Rv})$.

\section{Experimental}

\section{Preparation of complexes}

Commercial reagents and solvents were used for the synthesis: 2 -furoic acid (99\%, "J\&K"), $\mathrm{Zn}(\mathrm{AcO})_{2} \cdot 2 \mathrm{H}_{2} \mathrm{O}$ ( $\left.\geq 99 \%\right), \mathrm{Cu}(\mathrm{AcO})_{2}$ $\cdot 2 \mathrm{H}_{2} \mathrm{O}(\geq 99 \%), \mathrm{ZnO}(\geq 99 \%)$, neocuproine hemihydrate ( $\geq 99 \%$, "Acros Organics"), 3-aminopyridine ( $\geq 99 \%$, "Acros Organics"), acetonitrile $(\geq 99 \%)$, ethanol $(\geq 95 \%)$, $\mathrm{NaCl}(0.9 \%)$, dextrose $(5 \%), \mathrm{MeOH}, \mathrm{CHCl}_{3}, \mathrm{DMSO}$ and distilled water.

Synthesis of $\left[\mathrm{Zn}_{2}(\text { fur })_{4}\right]_{n}$ (1). $\mathrm{ZnO}(0.08 \mathrm{~g}, 1 \mathrm{mmol})$, Hfur $(0.230 \mathrm{~g}, \quad 2.05 \mathrm{mmol})$, were dissolved in mixture MeCN : EtOH : $\mathrm{H}_{2} \mathrm{O}\left(6: 1: 1\right.$, respectively) at $70{ }^{\circ} \mathrm{C}$, air and stirred until dissolution of $\mathrm{ZnO}$. The final solution was filtered and concentrated. Crystals were obtained after 24 hours. Yield $0.46 \mathrm{~g}$ (80\%). Anal. calc. $\mathrm{Zn}_{2} \mathrm{O}_{12} \mathrm{C}_{20} \mathrm{H}_{12}$ : C 41.81, $\mathrm{H}$ 2.1. Found: $\mathrm{C}$ 41.42, H 2.4. FT-IR (ATR), $\nu / \mathrm{cm}^{-1}: 3140 \mathrm{v} / \mathrm{w}, 2104 \mathrm{v} / \mathrm{w}, 1733 \mathrm{v} / \mathrm{w}$, 1634 m, 1583 s, 1558 s, 1543 s, 1473 vs., 1419 vs., 1373 vs., 1230 m, 1205 s, 1140 w, 1078 w, 1010 m, 937 m, 884 m, 835 w, 799 m, $777 \mathrm{~s}, 754$ vs., $612 \mathrm{~m}, 593 \mathrm{~m}, 577 \mathrm{w}, 515 \mathrm{~s}, 487 \mathrm{~m}, 451 \mathrm{v} / \mathrm{w}, 431 \mathrm{v} /$ $\mathrm{w}, 415 \mathrm{v} / \mathrm{w}, 407 \mathrm{v} / \mathrm{w}$.

Synthesis of complex $\left[\mathrm{Zn}_{2}(\text { fur })_{4}\left(\mathbf{N H}_{2} \mathrm{py}\right)_{2}\right](2) . \mathrm{Zn}(\mathrm{AcO})_{2} \cdot 2 \mathrm{H}_{2} \mathrm{O}$ $(0.220 \mathrm{~g}, 1 \mathrm{mmol})$, Hfur $(0.230 \mathrm{~g}, 2.05 \mathrm{mmol})$ and $3-\mathrm{NH}_{2}$ py $(0.100 \mathrm{~g}, 1 \mathrm{mmol})$, were dissolved in $20 \mathrm{ml} \mathrm{MeCN}\left(70{ }^{\circ} \mathrm{C}\right.$, air) and stirred for one and a half hour. The final solution was filtered and concentrated. Crystals were obtained after 24 hours. Yield $0.39 \mathrm{~g}$ (61\%). Anal. calc. $\mathrm{Zn}_{2} \mathrm{O}_{12} \mathrm{C}_{30} \mathrm{H}_{24} \mathrm{~N}_{4}$ : C 47.21, $\mathrm{H} 3.17, \mathrm{~N} 7.34$. Found: C 47.23, H 3.21, N 7.38. FT-IR (ATR), $\nu / \mathrm{cm}^{-1}$ : $3483 \mathrm{v} / \mathrm{w}$,
3389 w, 3226 v/w, 3145 v/w, 3123 v/w, 3058 v/w, 2167 v/w, 2148 v/w, 1712 v/w, 1640 vs., $1614 \mathrm{~s}, 1577$ vs., 1481 vs., 1454 m, 1412 vs., 1395 vs., 1368 vs., 1310 m, 1273 m, 1225 m, 1195 s, 1140 m, 1077 m, 1063 m, 1017 m, 1007 m, 935 m, 900 w, 883 m, 861 w, 800 s, 781 vs., 756 vs., $658 \mathrm{~m}, 696 \mathrm{~s}, 615 \mathrm{~m}, 597 \mathrm{~m}, 546 \mathrm{w}, 484 \mathrm{~s}$.

Synthesis of [ $\mathrm{Zn}$ (fur $)_{2}$ (neoc)] (3). $\mathrm{Zn}(\mathrm{AcO})_{2} \cdot 2 \mathrm{H}_{2} \mathrm{O}(0.220 \mathrm{~g}, 1$ $\mathrm{mmol}$ ), Hfur (0.230 g, $2.05 \mathrm{mmol}$ ) and neoc (0.210 g, $1 \mathrm{mmol})$, were dissolved in $20 \mathrm{ml} \mathrm{MeCN}\left(70{ }^{\circ} \mathrm{C}\right.$, air) and stirred for one and a half hour. The final solution was filtered and concentrated. Crystals were obtained after 24 hours. Yield $0.32 \mathrm{~g}(70 \%)$. Anal. calc. $\mathrm{ZnO}_{6} \mathrm{C}_{24} \mathrm{H}_{18} \mathrm{~N}_{2}$ : C 58.18, $\mathrm{H}$ 3.63, $\mathrm{N}$ 5.66. Found: $\mathrm{C}$ 58.31, H 3.63, N 5.72. FT-IR (ATR), $\nu / \mathrm{cm}^{-1}: 3121 \mathrm{v} / \mathrm{w}, 3071 \mathrm{v} / \mathrm{w}$, $2159 \mathrm{v} / \mathrm{w}, 1761 \mathrm{v} / \mathrm{w}, 1620 \mathrm{~m}, 1559 \mathrm{~m}, 1520 \mathrm{w}, 1474 \mathrm{~s}, 1394 \mathrm{~s}$, 1353 vs., 1297 m, 1228 m, 1193 s, 1164 w, 1135 m, 1108 m, 1075 m, 1011 s, 932 m, 883 m, 864 m, 845 m, 805 m, 771 vs., $751 \mathrm{~s}$, $728 \mathrm{~s}, 681 \mathrm{~m}, 661 \mathrm{~m}, 617 \mathrm{~m}, 598 \mathrm{~m}, 569 \mathrm{~m}, 549 \mathrm{~m}, 474 \mathrm{s.}{ }^{1} \mathrm{H}$ NMR (300 MHz, DMSO, 294 K): 3.09 (s, 6H, Me-neoc), 6.52 (dd, 2H, 4fur, $\left.{ }^{3} J_{\mathrm{H}-\mathrm{H}}=3.2 \mathrm{~Hz},{ }^{3} J_{\mathrm{H}-\mathrm{H}}=2.2 \mathrm{~Hz}\right), 6.96\left(\mathrm{~d}, 2 \mathrm{H}, 3\right.$-fur, ${ }^{3} J_{\mathrm{H}-\mathrm{H}}=$ $3.2 \mathrm{~Hz}$ ), 7.72 (brs, 2H, 5-fur), 8.05 (d, 2H, 3/8-neoc, ${ }^{3} J_{\mathrm{H}-\mathrm{H}}=8.4$ $\mathrm{Hz}$ ), 8.20 (s, 2H, 5/6-neoc), 8.83 (d, 2H, 4/7-neoc, ${ }^{3} J_{\mathrm{H}-\mathrm{H}}=8.4 \mathrm{~Hz}$ ). Mixture of ligands: ${ }^{1} \mathrm{H}$ NMR (300 MHz, DMSO, $294 \mathrm{~K}$ ): 2.79 (s, $6 \mathrm{H}$, Me-neoc), 6.65 (dd, $1 \mathrm{H}, 4$-fur, ${ }^{3} J_{\mathrm{H}-\mathrm{H}}=3.4 \mathrm{~Hz},{ }^{3} J_{\mathrm{H}-\mathrm{H}}=2.0$ $\mathrm{Hz}$ ), 7.20 (d, 1H, 3-fur, $\left.{ }^{3} J_{\mathrm{H}-\mathrm{H}}=3.4 \mathrm{~Hz}\right), 7.61$ (d, 2H, 3/8-neoc, ${ }^{3} J_{\mathrm{H}-}$ $\mathrm{H}=8.2 \mathrm{~Hz}$ ), 7.86 (s, 2H, 5/6-neoc), 7.91(brs, 1H, 5-fur), 8.34 (d, $2 \mathrm{H}, 4 / 7$-neoc, ${ }^{3} \mathrm{~J}_{\mathrm{H}-\mathrm{H}}=8.2 \mathrm{~Hz}$ ), 13.09 (brs, 1H, 2-fur).

Synthesis of $\left[\mathrm{Zn}(\mathrm{AcO})_{2}\right.$ (neoc) $]$ (4). $\mathrm{Zn}(\mathrm{AcO})_{2} \cdot 2 \mathrm{H}_{2} \mathrm{O}(0.220 \mathrm{~g}, 1$ $\mathrm{mmol})$ and neoc $(0.210 \mathrm{~g}, 1 \mathrm{mmol})$, were dissolved in $20 \mathrm{ml}$ $\operatorname{MeCN}\left(70{ }^{\circ} \mathrm{C}\right.$, air) and stirred for one and a half hour. The final solution was filtered and concentrated. Crystals were obtained after 24 hours. Yield $0.27 \mathrm{~g}(70 \%)$. Anal. calc. $\mathrm{ZnO}_{4} \mathrm{C}_{18} \mathrm{H}_{18} \mathrm{~N}_{2}$ : C 55.24, H 4.6, N 7.16. Found: C 55.31, H 4.65, N 7.20. FT-IR (ATR), $\nu / \mathrm{cm}^{-1}: 3052 \mathrm{v} / \mathrm{w}, 2997 \mathrm{v} / \mathrm{w}, 2927 \mathrm{v} / \mathrm{w}, 1616 \mathrm{~s}, 1590 \mathrm{~s}, 1567 \mathrm{~s}, 1503$ m, 1421 s, 1378 vs., 1327 s, 1226 w, 1158 w, 1009 m, 924 brw, $867 \mathrm{~s}, 813 \mathrm{w}, 779 \mathrm{w}, 732 \mathrm{w}, 677$ vs., $618 \mathrm{~m}, 549 \mathrm{~m}, 501 \mathrm{w}, 434 \mathrm{~m}$, $405 \mathrm{~m}$.

Synthesis of $\left[\mathrm{Cu}(\text { fur })_{2}\right.$ (neoc) $\left.\mathbf{H}_{2} \mathrm{O}\right] \quad$ (5). $\mathrm{Cu}(\mathrm{AcO})_{2} \cdot 2 \mathrm{H}_{2} \mathrm{O}$ $(0.220 \mathrm{~g}, 1 \mathrm{mmol})$, Hfur $(0.224 \mathrm{~g}, 2 \mathrm{mmol})$ and neoc $(0.208 \mathrm{~g}, 1$ mmol) were dissolved in mixture $\mathrm{MeCN}: \mathrm{CHCl}_{3}: \mathrm{MeOH}$ (in a ratio of $4: 2: 1$, respectively; $60^{\circ} \mathrm{C}$, air) and stirred for one and a three hours. The final yellow-green solution was filtered and concentrated. Green crystals were obtained after 24 hours. Yield $0.42 \mathrm{~g}(82 \%)$. Anal. calc. $\mathrm{CuO}_{7} \mathrm{C}_{24} \mathrm{H}_{20} \mathrm{~N}_{2}$ : C 56.30, H 3.94, N 5.47. Found: C 56.38, H 3.89, N 5.48. FT-IR (ATR), $\nu / \mathrm{cm}^{-1}$ : $3119 \mathrm{w}$, $1596 \mathrm{~s}, 1548 \mathrm{~m}, 1474 \mathrm{~s}, 1395 \mathrm{~s}, 1353$ vs., $1223 \mathrm{~m}, 1189 \mathrm{~s}, 1134 \mathrm{~m}$, $1074 \mathrm{~m}, 1012 \mathrm{~m}, 931 \mathrm{~m}, 862 \mathrm{~m}, 808$ s, 772 vs., 726 s, $597 \mathrm{~m}$, $542 \mathrm{~s}, 470 \mathrm{~s}, 418 \mathrm{~m}$.

\section{IR spectra and $\mathrm{CHN}$}

IR spectra were recorded in the $400-4000 \mathrm{~cm}^{-1}$ region using a Spectrum-65 PerkinElmer FT-IR spectrometer. Microprobe analyses were carried out using an Carlo Erba EA 1108 Series CHN Elemental Analyser (Center of Collective Use of IGIC RAS).

\section{NMR spectra}

${ }^{1} \mathrm{H}$ and DOSY NMR spectra were recorded from DMSO solutions with a Bruker Avance 300 FT-NMR spectrometers $\left({ }^{1} \mathrm{H}\right.$ frequency: 
300.13 MHz) equipped with $5 \mathrm{~mm}$ probe with Z-gradient. All spectra were referenced to the chemical shift of a deuterated solvent $\left({ }^{1} \mathrm{H} 2.50 \mathrm{ppm}\right)$. The 2D DOSY spectra were obtained using a bipolar gradient pulse sequence (LEDbpgp2s) with preequilibrated for 10 minutes inside spectrometer at $305 \mathrm{~K}$ and processed with Bruker 2.1 TOPSPIN. Parameters of $90^{\circ}$ angle and gradient pulses were determined manually (see details in ESI $\dagger$ ). Two samples were prepared for the taking ${ }^{1} \mathrm{H}$ NMR and DOSY spectra. The first one with the complex 3 and the second one with ligands mixture, which were taken with the stoichiometric ratio neoc $:$ Hfur $=1: 2$.

\section{X-ray crystallography}

X-ray diffraction experiments for 1, 3-5 were carried out at $120 \mathrm{~K}$ with a Bruker APEX2 DUO CCD diffractometer, those for 2 at $150 \mathrm{~K}$ with a Bruker AXS Smart Apex II CCD diffractometer, both using graphite monochromated Mo-K $\alpha$ radiation $(l=0.71073$ $\AA$ ). Using Olex $2,{ }^{36}$ the structures were solved with the ShelXT ${ }^{37}$ structure solution program using Intrinsic Phasing and refined with the olex2.refine ${ }^{38}$ refinement package using Gauss-Newton minimization against $F^{2}$ in anisotropic approximation for nonhydrogen atoms. Hydrogen atoms of $\mathrm{NH}$ groups in 2 were located from difference Fourier synthesis; positions of other hydrogen atoms were calculated, and they all were refined in isotropic approximation within the riding model. Crystal data and structure refinement parameters for 1-5 are given in Table S1. CCDC 2112367 (1), 2112368 (2), 2112369 (3), 2112370 (4) and 2115090 (5) contain the supplementary crystallographic data for this paper (Table $\mathrm{S} 1 \dagger$ ).

\section{Spectroscopy and stability}

The UV-vis spectra were obtained using Shimadzu UV-2600 spectrophotometer in SoloPharm $0.9 \% \mathrm{NaCl}$ and SoloPharm $5 \%$ glucose solutions in the range of $220-400 \mathrm{~nm}$. The stability of the complexes in solution was monitored by measuring the spectra of the sample $(50 \mu \mathrm{M})$ once every 2 hours for 48 hours at room temperature.

\section{Antibacterial activity}

To determine the biological activity of substances 1-5 possessing anti-tuberculosis properties in the M. smegmatis $m c^{2} 155$ test system, the paper disk method was used. The technique involved determining the size of the zone of inhibition of the growth of the strain seeded as a lawn on an agar medium, around paper disks containing the compound in various concentrations. The bacteria washed off Petri dishes with tryptone soya agar M-290 medium (Himedia) were grown overnight in Lemco-TW liquid medium (Lab Lemco' Powder $5 \mathrm{~g} \mathrm{~L}^{-1}$ (Oxoid), peptone special $5 \mathrm{~g} \mathrm{~L}^{-1}$ (Oxoid), NaCl $5 \mathrm{~g} \mathrm{~L}^{-1}$, Tween80) at $+37{ }^{\circ} \mathrm{C}$ until the average logarithmic growth phase at optical density OD600 $=1.5$, then mixed with molten agar medium M-290 in a ratio of $1: 9: 10$ (culture : Lemco-TW : M290) and the resulting mixture was poured as a top layer onto Petri dishes, $5 \mathrm{ml}$ per dish, with $20 \mathrm{ml}$ already solidified M-290 agar medium. After the agar in the top layer solidified, paper disks soaked with a solution of the test substance were placed on the plate surface. The culture was incubated for 24 hours at $+37{ }^{\circ} \mathrm{C}$. The diameter of the zone of inhibition of M. smegmatis $m c^{2} 155$ growth around the paper disk impregnated with the compound was determined. The MIC (minimum inhibiting concentration) was taken as the concentration of the compound where the zone of growth inhibition was the smallest.

\section{Transcriptome data analysis (RNA-seq)}

Total RNA extracted from six independent samples (three control replicates - untreated cultures, and three experimental replicates - treated with an cooper complex) subjected to RNA sequencing. M. smegmatis cultures were grown in Middlebrook 7H9 medium (Himedia, India) supplemented with $0.05 \%(\mathrm{v} / \mathrm{v})$ Tween 80 and $0.5 \%(\mathrm{v} / \mathrm{v})$ glycerol at $37{ }^{\circ} \mathrm{C}$ and $250 \mathrm{rpm}$ before OD600 = 1,2 (log-phase of growth). Then copper complex was added to experimental culture at a concentration of $\frac{1}{4}$ MIC (MIC was previously determined in liquid medium), and the culture was incubated at $37{ }^{\circ} \mathrm{C}$ and $250 \mathrm{rpm}$ for 90 minutes. Untreated culture was incubated under the same conditions for 90 minutes. Cells from $30 \mathrm{ml}$ culture were harvested by centrifugation for $10 \mathrm{~min}$ at $4000 \times g$ and $4{ }^{\circ} \mathrm{C}$, washed by $40 \mathrm{ml}$ of fresh Middlebrook 7H9 broth. Total RNA was extracted as described by Rustad et al. ${ }^{39} M$. smegmatis cells were homogenized in extractRNA reagent Trizol (Invitrogen, USA), followed by phenol $(\mathrm{pH}=4.5)$-chloroform/isoamyl alcohol (25:24:1) purification, precipitation with isopropanol $(2: 1, \mathrm{v} / \mathrm{v})$ and washed with $80 \%$ ethanol. Remaining genomic DNA was removed by DNAse I (Invitrogen, USA). Ribosomal RNA was removed using the RiboZero Plus rRNA Depletion Kit (Illumina) and libraries were prepared using the NEBNext@ Ultra II Directional RNA Library Prep Kit (NEB). Libraries were subsequently quantified by Quant-iT DNA Assay Kit, High Sensitivity (Thermo Fisher Scientific). Equimolar quantities of libraries were sequenced by a high throughput run on the Illumina HiSeq using $2 \times 100 \mathrm{bp}$ paired-end reads and a 1\% phiX-in control. Raw reads of the $M$. smegmatis $m c^{2} 155$ transcriptome with the complex lie in the NCBI database (Bioproject https:/www.ncbi.nlm.nih.gov/ bioproject/PRJNA747161). Raw reads' quality was assessed by FASTQC v0.11.9. ${ }^{40}$ The remaining adapters were removed with Trimmomatic v0.39. ${ }^{41}$ Reads were mapped to the $M$. smegmatis $m c^{2} 155$ reference assembly (CP000480.1) and quantified with HISAT2 v.2.2.1. ${ }^{42}$ Differential expression analysis was performed using edgeR v3.30.3 package. $^{43}$

\section{Results and discussion}

\section{Synthesis of complexes 1-5}

A small nuclearity of the complex should most likely be one of the main criteria for the would-be coordination-based chemotherapy drugs against tuberculosis (by analogy with the Lipinski's rule that imposes certain restrictions on hypothetical organic pharmaceuticals). Scheme 1 shows the synthesis routes for complexes 1-5. In contrast to $\mathbf{2 - 5}$, polymer complex $\mathbf{1}$ was obtained from the oxide, whereas the adducts with $\mathrm{N}$-donor ligands for 2-5 were synthesized from acetates by anion exchange reactions. 


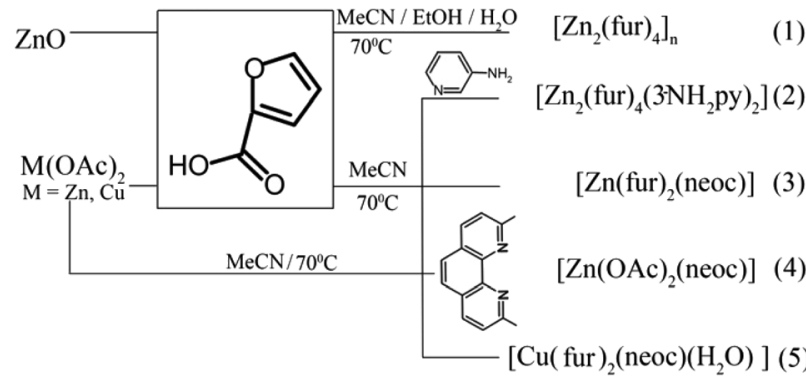

Scheme 1 Synthetic routes to compounds $1-5$.

\section{Single crystal X-ray structure of 1-5}

As identified by X-ray diffraction, the compound 1 (Fig. 1) is a 1D-coordination polymer with two symmetry-independent zinc(II) ions and four fur ${ }^{-}$anions. Each metal ion coordinates four anions (Table 1) that form its distorted tetrahedral coordination environment.

Carboxylate groups of the three bridging anions bind these two zinc(II) ions to produce binuclear nodes ( $\mathrm{Zn}-\mathrm{O}$ 1.925(2)1.966(2) $\AA, \mathrm{Zn} \cdots \mathrm{Zn} 3.3066(5) \AA)$ that are connected to each other by one carboxylate group (Zn-O 1.9293(19), 1.9672(18) $\AA$, Zn $\cdots$ Zn $4.4320(5) \AA$ A) to produce zigzag 1D-polymer chains as sometimes found in other 1D-coordination polymers based on transition metals and carboxylate-derived ligands (see, e.g..$^{44,45}$ ). In the crystal of $\mathbf{1}$, these chains run along the crystallographic axis $b$ with the separation $\mathrm{Zn}(1) \cdots \mathrm{Zn}(2)$ and an angle $\mathrm{Zn}(1) \mathrm{Zn}(2)$ $\mathrm{Zn}(1)$ are 3.306(2) $\AA$ and $116.60(1)-145.84(1)^{\circ}$, respectively. They are held together only by weak interactions, such as $\mathrm{C}-\mathrm{H} \cdots \mathrm{O}$, $\pi \cdots \pi$ and $\mathrm{H} \cdots \mathrm{H}$ contacts (Fig. 2).

Molecules of binuclear zinc complex 2 in the crystal are in a special position at the crystallographic inversion center.

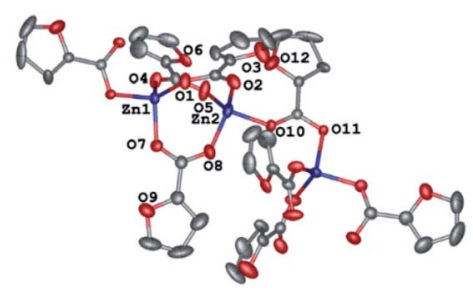

Fig. 1 A fragment of a 1D-coordination polymer chain in the crystal of 1. Hereinafter, hydrogen atoms $\mathrm{H}(\mathrm{C})$ and minor components of the disordered anions are omitted for clarity, non-hydrogen atoms are shown as thermal ellipsoids at $50 \%$ probability level, and labels are given for symmetry-independent heteroatoms only.

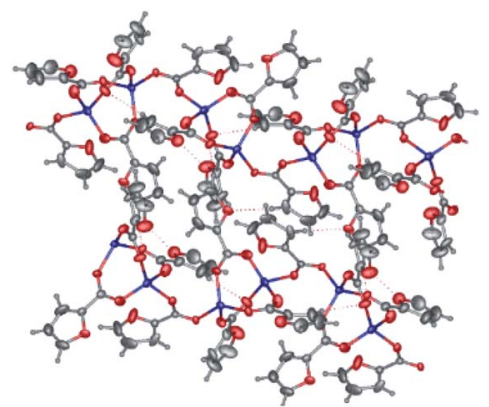

Fig. 2 Formation of a 1D polymer chain for 1.

Inversion center is located between the two $\mathrm{Zn}$ atoms. Zinc ions in 2 have a square pyramid $(\tau=0.008, \mathrm{O} 1, \mathrm{O} 2, \mathrm{O} 4$ and $\mathrm{O} 5$ atoms lie at the base of the pyramid) formed by four bridging fur ${ }^{-}$ anions and one monodentate aminopyridine ligand $(\mathrm{CN}=5)$ (Fig. 3). The distances $\mathrm{Zn}-\mathrm{O}, \mathrm{Zn}-\mathrm{N}$ and $\mathrm{Zn} \cdots \mathrm{Zn}$, are given in Table 1.

The molecule consists of two almost perpendicular flat fragments (the angle between the planes Zn1-N1-C1 and Zn1C6-Zn1 is $86.93^{\circ}$ ) with some deviation of the oxygen atoms of the carboxyl groups and the aromatic fragments. Thus, the fur ${ }^{-}$ and aminopyridine fragments are deployed relative to the Zn1$\mathrm{N} 1-\mathrm{C} 1$ plane at $9.63^{\circ}$ and $19.13^{\circ}$ respectively, and the furan cycle is deployed relative to the Zn1-C6-Zn1 plane at $18.19^{\circ}$. The molecular packing in a crystal consists of infinite layers parallel to the $a 0 b$ plane, formed by the classical $\mathrm{NH}^{\cdots} \mathrm{O}$ hydrogen bonds and additionally stabilized by $\pi \cdots \pi$

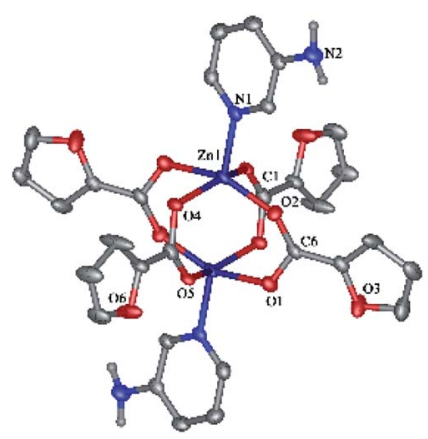

Fig. 3 General view of 2 in representation of atoms as thermal ellipsoids at $50 \%$ probability level. Hydrogen atoms except those of $\mathrm{NH}$ groups and minor components of the disordered anions are omitted for clarity and labels are shown for symmetry-independent heteroatoms only.

Table 1 Selected distances $(\AA ̊)$ for $1-5$

\begin{tabular}{|c|c|c|c|c|c|}
\hline & \multicolumn{5}{|l|}{ Compounds } \\
\hline & 1 & 2 & 3 & 4 & 5 \\
\hline $\mathrm{M}-\mathrm{N}$ & - & $2.0237(14)$ & $2.057(2), 2.070(2)$ & $2.082(3), 2.102(3)$ & $2.020(4), 2.254(4)$ \\
\hline $\mathrm{Zn} \cdots \mathrm{Zn}$ & $3.3066(5)$ & $3.0193(3)$ & - & - & - \\
\hline
\end{tabular}




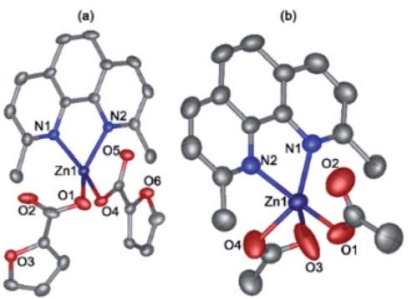

Fig. 4 Molecular structures of 3 (a) and 4 (b).

interactions of aromatic fragments (the distances between the centroids of the rings are 3.4-3.9 $\AA$, between the planes 3.5-3.6 $\AA$ ). The layers are linked by $\mathrm{CH}^{\cdots} \mathrm{O}$ interactions (Table 3 ).

Compounds 3 (Fig. 4a) and 4 (Fig. 4b) have a very similar molecular structures (Table 1) with the zinc ion binding one neoc ligand (Zn-N 2.057(2)-2.102(3) $\AA$ ) and two fur ${ }^{-}{\text {or } \mathrm{Ac}^{-}}^{-}$ anions (Zn-O 1.9485(18)-1.976(2) and 1.911(3)-2.43(3) ̊) that coordinate it in a monodentate mode or in monodentate and chelate modes, respectively, as often found in other transition metal complexes with phenanthroline- and carboxylate-derived ligands (see, e.g.). ${ }^{46}$ The resulting coordination environment of the zinc(II) ions in $\mathbf{3}$ is a distorted tetrahedron while in $\mathbf{4}$, it is better described as a square pyramid $(\tau=0.18 ; \mathrm{O} 1, \mathrm{O} 4, \mathrm{~N} 1$ and $\mathrm{N} 2$ atoms lie at the base of the pyramid).

In both crystals, the aromatic neoc ligands form paralleldisplaced stacking interactions with intercentroid and shift distances of 3.566(2)-3.887(2) and 1.074(2)-1.762(2) $\AA$ and an angle between the planes of $0.0(5)-1.94(2)^{\circ}$. They, however, pack the molecules of these complexes into two different types of supramolecular associates, the infinite chains in 3 (Fig. 5a) and centrosymmetric dimers in $\mathbf{4}$ (Fig. 5b); the latter are held together by weak intermolecular $\mathrm{C}-\mathrm{H} \cdots \mathrm{O}$ contacts to produce similar infinite chains along the crystallographic axis $a$.

In contrast, the metal ion in the discrete copper(II) complex 5 (Fig. 6, Table 2) coordinates one neoc ligand in a bidentate mode $\left(\mathrm{Cu}-\mathrm{N}\right.$ 2.020(4), 2.254(4) $\AA$ ), two fur ${ }^{-}$anions $(\mathrm{Cu}-\mathrm{O}$ $1.954(2), 1.981(2) \AA)$ and an additional water molecule $(\mathrm{Cu}-\mathrm{O}$ $1.981(2) \AA)$ to produce a distorted square pyramid coordination environment $(\mathrm{CN}=5 ; \tau=0.07 ; \mathrm{O} 1, \mathrm{O} 4, \mathrm{O} 10 \mathrm{~N} 2$ atoms form the base of the pyramid).

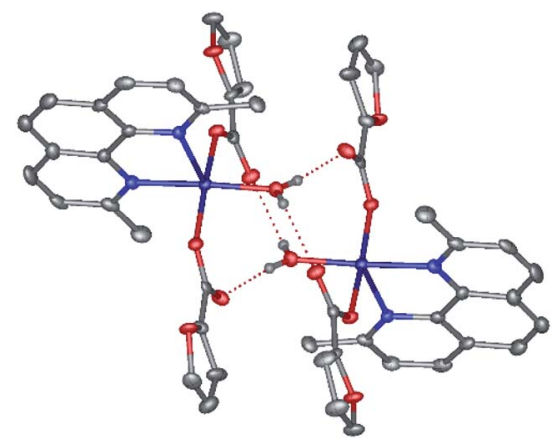

Fig. 6 A fragment of crystals packing 5 illustrating the formation of centrosymmetric dimers by $\mathrm{O}-\mathrm{H} \cdots \mathrm{O}$ hydrogen bonds.

Table $2 \mathrm{H}$-bonds in crystal of 2 and 5

\begin{tabular}{lllll}
\hline H-bond & $\mathrm{D}-\mathrm{H}, \AA$ & $\mathrm{H} \cdots \mathrm{A}, \AA$ & $\mathrm{D} \cdots \mathrm{A}, \AA$ & $\mathrm{D}^{-} \mathrm{H} \cdots \mathrm{A},{ }^{\circ}$ \\
\hline 2 & & & & \\
$\mathrm{~N} 2-\mathrm{H} 2 \mathrm{~A} \cdots \mathrm{O} 6$ & 0.91 & 2.32 & $3.175(11)$ & 156 \\
$\mathrm{~N} 2-\mathrm{H} 2 \mathrm{~A} \cdots 6^{\prime}$ & 0.91 & 2.29 & $3.110(13)$ & 149 \\
$\mathrm{~N} 2-\mathrm{H} 2 \mathrm{~B} \cdots \mathrm{O} 1$ & 0.87 & 2.53 & $3.169(7)$ & 131 \\
$\mathrm{C} 5^{\prime}-\mathrm{H} 5^{\prime} \cdots 4^{\prime}$ & 0.95 & 2.39 & $3.214(11)$ & 145 \\
$\mathrm{C} 8-\mathrm{H} 8 \cdots \mathrm{O} 3$ & 0.95 & 2.45 & $3.32(2)$ & 153 \\
$\mathrm{C} 13-\mathrm{H} 13 \cdots 5^{\prime}$ & 0.95 & 2.51 & $3.324(17)$ & 144 \\
$\mathrm{C} 15-\mathrm{H} 15 \cdots \mathrm{O} 1$ & 0.95 & 2.56 & $3.180(15)$ & 123 \\
& & & & \\
5 & & & & \\
O10-H10 $\cdots \mathrm{O} 5$ & 0.87 & 1.84 & $2.638(4)$ & 123 \\
$\mathrm{O} 10-\mathrm{H} 10^{\mathrm{a}} \cdots \mathrm{O} 2$ & 0.85 & 2.07 & $2.695(3)$ & 167 \\
& & & &
\end{tabular}

The molecules of the complex are assembled into centro-

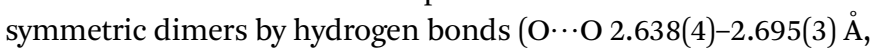
OHO $123.7(3)-167(5)^{\circ}$ ) between the above water molecule and oxygen atoms of the anions that are not involved in the coordination to the copper(II) ion. Despite the presence of the aromatic neoc ligand, no stacking interactions are observed for 5 .

\section{UV-vis spectroscopy studies}

The electronic absorption spectra of 1-5 $\left(5 \times 10^{-5} \mathrm{M}\right)$ were collected in saline $(0.9 \% \mathrm{NaCl})$ and $5 \%$ dextrose containing saline (a)

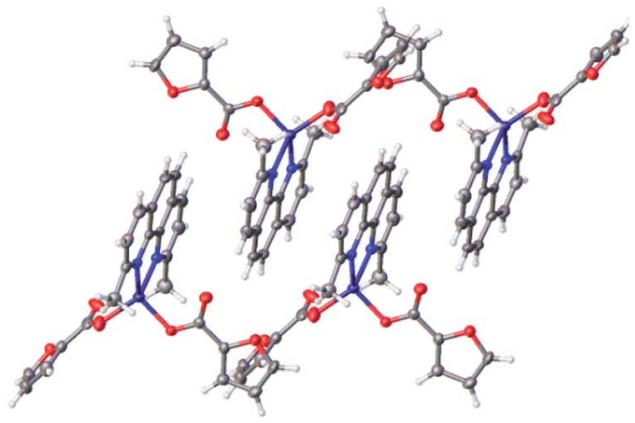

(b)

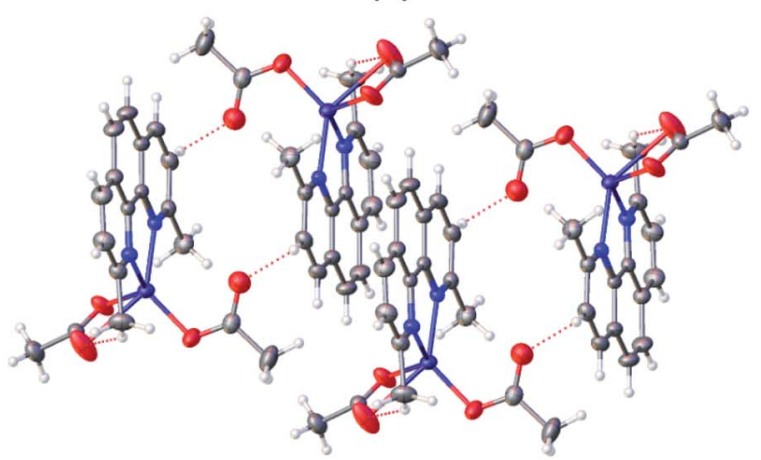

Fig. 5 General view of a fragments crystals packing 3 (a) and 4 (b) illustrating the formation of infinite chains by stacking interactions between the neoc ligands. 

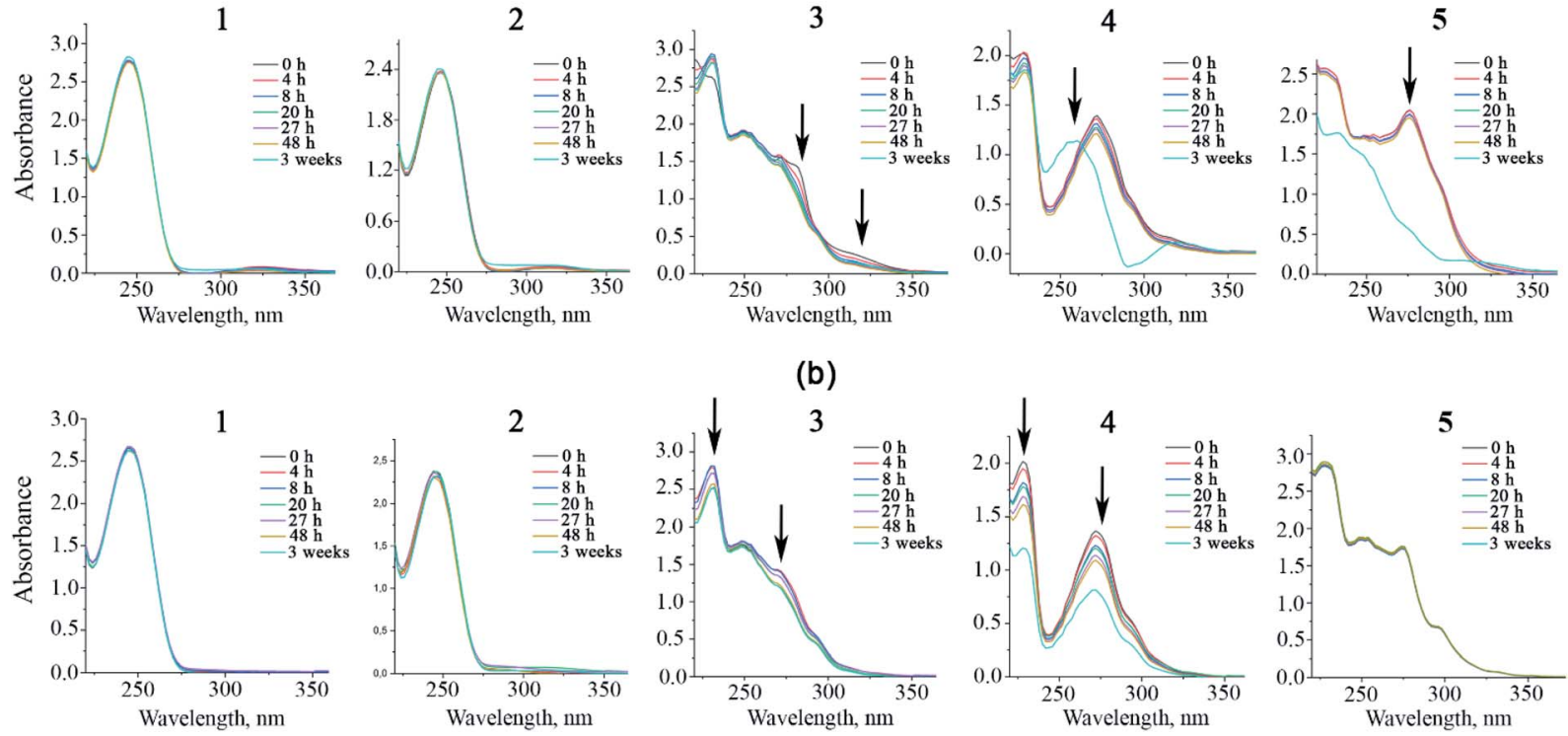

Fig. 7 UV-vis spectra in $5 \%$ dextrose (a) and $0.9 \% \mathrm{NaCl}(\mathrm{b})$ at room temperature.

for 48 hours at room temperature (Fig. 7a and b). Additionally, the investigated samples were stored for extra 3 weeks to check its long-term stability in the given conditions. All complexes exhibit high absorption rates in the high-energy region. For compounds 1 and 2, the absorption band at $250 \mathrm{~nm}$ is conditioned by effective intraligand $\pi-\pi^{*}$ and $\mathrm{n}-\pi^{*}$ transitions within the fur ${ }^{-}$ ligands. ${ }^{47}$ Complexes 3-5 show the additional red-shifted bands at about $275 \mathrm{~nm}$ correspond to intraligand transitions within coordinated neocuproine. For all complexes, low intensity absorption bands lying in the region of 300-350 $\mathrm{nm}$ are attributed to metal-to-ligand charge-transfer (MLCT) ${ }^{48,49}$ Saline solutions of 1, 2 and 5 are stable at room temperature for 48 hours, as no significant changes in the absorbance were noticed. However, prolonged storage of aforementioned species resulted in general decreasing of absorbance because of complex aggregation processes. ${ }^{50}$ Dextrose containing solutions of $\mathbf{1}$ and $\mathbf{2}$ have similar short term stability, but upon the storage for over 3 weeks, a new broad low intensity absorption band appears at 275-300 nm region, probably caused by anion exchange and overall partial hydrolysis of the species (Fig. 7a). ${ }^{51}$ Both saline and dextrose solutions of $\mathbf{3}$ and $\mathbf{4}$ show similar absorption intensity decrease within first 48 hours. Such spectral changes indicate that upon given conditions the complexes are slowly hydrolyzing. Nevertheless, the hydrolysis rate of both complexes in saline solutions are rather low, as the process is still going even after 3 weeks of storage. Complex 4 and $\mathbf{5}$ seems to be less stable in dextrose solution. After 3 weeks of storage, a completely new blue-shifted absorption band assigned to a different complex stoichiometry appeared.

\section{NMR $\left({ }^{1} \mathbf{H}\right)$}

The formation of donor-acceptor bond between a metal ion and a ligand leads to a redistribution of electron density distribution of the latter. As a result, it affects to chemical shift values of ligand's nuclei. ${ }^{52,53}$ Experimental ${ }^{1} \mathrm{H}$ NMR spectra show that signals of all protons are shifted in the spectrum of the complex in comparison with the spectrum of ligands mixture (Tables S2 and S3; $\uparrow$ Fig. 8), which proves the stability of the complex 3 in solution. The full assignment of protons for the ligands mixture and complex 3 samples presented in experimental section.

Diffusion. In contrast to DOSY spectrum of complex 3 , the spectrum of ligands mixture clearly indicates two different selfdiffusion coefficients for neoc and Hfur. Also, self-diffusion coefficient is inversely related to the molecule size, so for complex dissuasion must vary significantly from ligands coefficients that also proved by experimental values of diffusion coefficient (see ESI $2 \dagger$ ). The quantitative relation between size of molecule and diffusion coefficient is possible to determine with the Stokes-Einstein eqn (1) which relating the self-diffusion coefficient $(D)$ at a constant temperature $(T)$ with the viscosity of solution $(\eta)$ and hydrodynamic radius of a spherical particle $(r)$.

$$
D=\frac{k_{\mathrm{B}} T}{6 \pi \eta r}
$$

The Stokes-Einstein equation implies the relation between diffusion coefficient and radius of molecule for the spherical particles. However, the molecular shape of particles is not necessarily spherical. In general, the ratio for two different particles with diffusion coefficients $D_{j}, D_{i}$ in same viscosity samples is inverse proportional to the third-degree root of their molecular weights ratio for spherical particles and to the root for elongated spheroids. ${ }^{53}$ In this way the ration of self-diffusion coefficients for two different species should be in the range represented in expression 2 .

$$
\sqrt[3]{\frac{M_{j}}{M_{i}}} \leq \frac{D_{i}}{D_{j}} \leq \sqrt{\frac{M_{j}}{M_{i}}}
$$




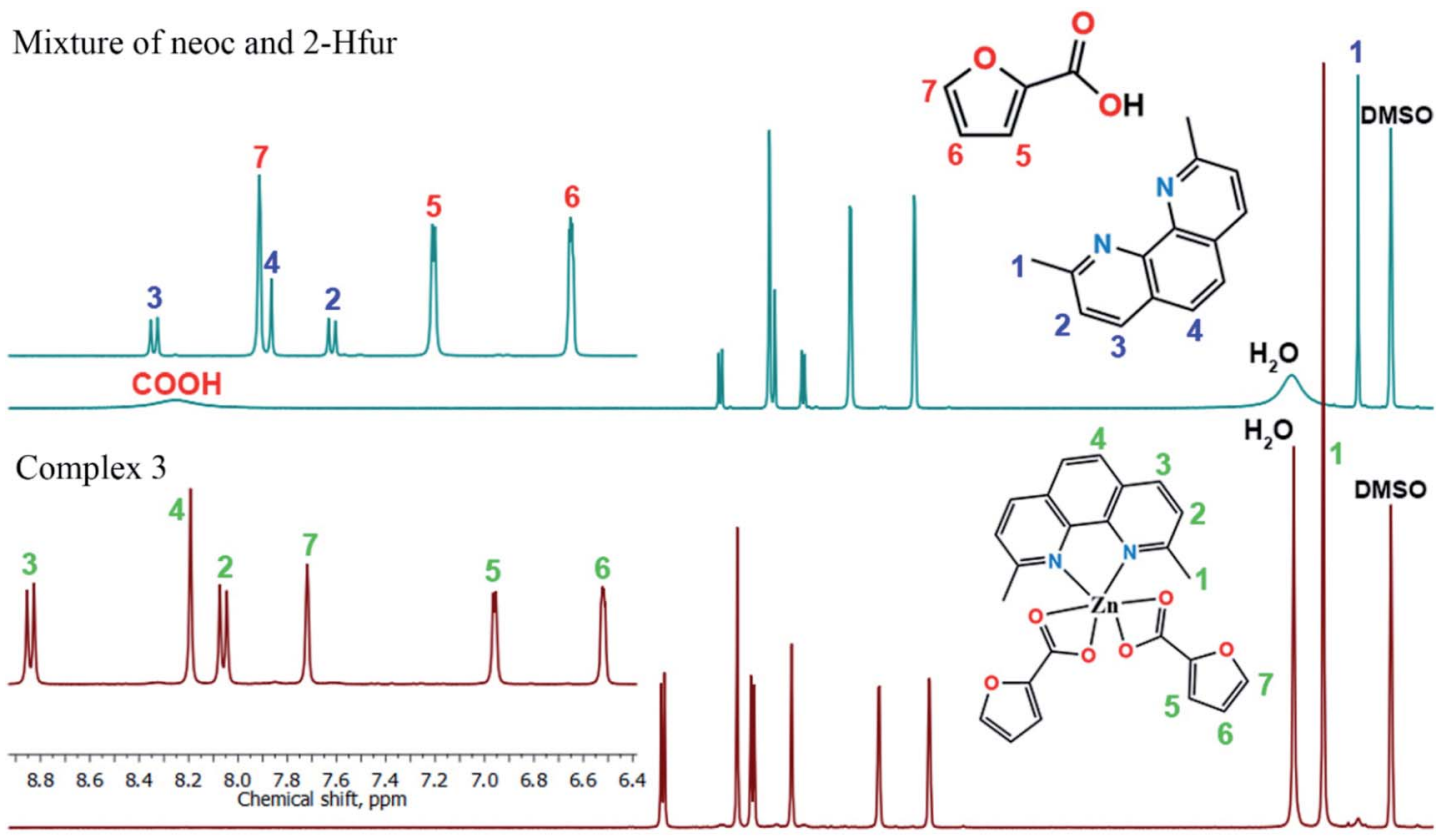

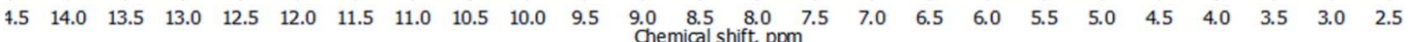

Fig. 8 The comparison of a mixture and complex $3\left({ }^{1} \mathrm{H}\right)$ NMR spectra.

where $D_{i}, D_{j}$ - experimental values of self-diffusion coefficients for $i$ th and $j$ th particles in solutions with equals viscosity. $M_{i}, M_{j}$ - molecular weights of these species.

The experimental diffusion coefficients were obtained for two different samples described in experimental section. Thus, we need know viscosities of two samples to determine selfdiffusion coefficients but as mentioned in ref. 54 the ration of self-diffusion coefficients of a molecule and a reference compound is independent of viscosity of solution. Hence, using DMSO as internal standard for two samples we can obtain the "true" ration of self-diffusion coefficient of the complex and ligands. The expression 3 defining viscosity-independent ratio for neocuproine and complex 3 self-diffusion coefficients is 1.34 that in good agreement with spherical particles approximation (1.34) according to eqn (2) and proves the stability of complex in a solution. All experimental self-diffusion coefficients and DOSY spectra can be found in ESI. $\dagger$

$$
\frac{D_{\text {mix }}^{\text {neoc }}}{D_{\text {mix }}^{\text {DMSO }}} \frac{D_{\text {complex }}^{\text {DMSO }}}{D_{\text {complex }}}=1.34=\sqrt[3]{\frac{M_{\text {complex }}}{M_{\text {neoc }}}}
$$

where $D_{\text {mix }}^{\text {DMSO }}, D_{\text {complex }}^{\text {DMSO }}$ - experimental values of DMSO selfdiffusion coefficients in the mixture and complex samples. $D_{\text {mix }}^{\text {neoc }}, D_{\text {complex }}$ - experimental values of neocuproine and complex 3 self-diffusion coefficients in the mixture and complex samples.

\section{Antibacterial activity}

The antibacterial activity of compounds $\mathbf{1 - 5}$, was determined in vitro against a non-pathogenic $M$. smegmatis strain. It is known that the resistance of mycobacteria to chemotherapeutic agents is due to the low permeability of the mycobacterial cell wall that has an unusual structure. M. smegmatis are fast-growing nonpathogenic bacteria and are therefore used as organisms simulating the slow-growing $M$. tuberculosis bacteria, as well as for primary screening of anti-tuberculosis drugs. ${ }^{55}$ The $M$. smegmatis test system exhibits a higher degree of resistance to antibiotics and antituberculosis agents than M. tuberculosis, therefore the selection criterion is a compound concentration of $<100 \mu \mathrm{g}$ per disc., in contrast to M. tuberculosis (MIC $<2 \mu \mathrm{g}$ $\left.\mathrm{ml}^{-1}\right) .{ }^{56}$ All the results obtained for in vitro bioactivity of the compounds studied were compared to the activity of isoniazid (INH) and rifampicin (Rif), i.e., the first line drugs for tuberculosis treatment under these experimental conditions. The concentration of the compound at which the minimum visible zone of growth inhibition is observed is considered as the MIC (minimum inhibitory concentration, $\mu \mathrm{g}$ per disc.). The biological activity of individual Hfur against $M$. smegmatis is comparable to that of INH (Table 3) but this effect persists for only one day. The results of antibacterial activity in the M. smegmatis $m c^{2}$ 155 test system and its variation over time for compounds 1-5 are shown in Table 3. Polymer complex 1 shows the smallest activity (534 $\mu \mathrm{g}$ per disk) among the compounds obtained (Table 3). Indeed, a considerable body of experimental data shows that in the absence of additional ligands (for example, $\mathrm{N}$ donor ones), furancarboxylate complexes of $\mathrm{Cu}^{\mathrm{II}}, \mathrm{Zn}^{\mathrm{II}}, \mathrm{Co}^{\mathrm{II}}$, and $\mathrm{Fe}^{\mathrm{III}}$ exhibit low in vitro biological activity with respect to $M$. smegmatis. ${ }^{57-59}$ Moreover, it was noted that pyridine, aminopyridine, and phenylpyridine (in the case of copper complexes) could hinder the biological efficiency of compounds with respect to the strain..$^{31-34}$ In contrast, 1,10-phenanthroline and 
Table 3 The results of antibacterial activity against M. smegmatis ${ }^{a}$

\begin{tabular}{|c|c|c|c|c|}
\hline \multirow[b]{2}{*}{ Compounds } & \multirow{2}{*}{$\begin{array}{l}\text { MIC, } \mu \mathrm{g} \\
\text { per disk }\end{array}$} & \multicolumn{2}{|c|}{ The zone of inhibition, $\mathrm{mm}$} & \multirow[b]{2}{*}{ Ref. } \\
\hline & & $24 \mathrm{~h}$ & $120 \mathrm{~h}$ & \\
\hline 1 & 534 & $6.6 \pm 0.3$ & $6.5 \pm 0^{b}$ & This work \\
\hline 2 & 380 & $6.5 \pm 0.1$ & $0^{d}$ & This work \\
\hline 3 & 50 & $7.1 \pm 0.3$ & $6.5 \pm 0.5^{c}$ & This work \\
\hline$\left[\mathrm{Cu}(\text { fur })_{2}(\right.$ phen $\left.)\right]$ & 2 & $7.0 \pm 0.5$ & $7.0 \pm 0.5^{c}$ & 31 \\
\hline$\left[\mathrm{Fe}_{3} \mathrm{O}(\text { fur })_{6}(\mathrm{THF})_{3}\right] \cdot 3 \mathrm{THF}$ & 13 & $7.0 \pm 0.5^{c}$ & $0^{d}$ & 33 \\
\hline$\left[\mathrm{Zn}_{2}(\text { fur })_{4}(\mathrm{phpy})_{2}\right]$ & 41 & $6.5 \pm 0.5^{c}$ & $6.5 \pm 0.5^{c}$ & 31 \\
\hline$\left[\mathrm{Zn}(\text { fur })_{2}(\mathrm{bpy})\right]$ & 44 & $6.5 \pm 0.5^{c}$ & $6.5 \pm 0.5^{c}$ & 32 \\
\hline$\left[\mathrm{Cu}(\text { fur })_{2}(\right.$ bpy $\left.)\left(\mathrm{H}_{2} \mathrm{O}\right)\right]$ & 46 & $7.0 \pm 0.5$ & $7.0 \pm 0.5^{b}$ & 32 \\
\hline$\left[\mathrm{Co}_{3}(\text { fur })_{6}(\text { phen })_{2}\right]$ & 60 & $7.0 \pm 0.5$ & $7.0 \pm 0.5^{b}$ & 33 \\
\hline$\left[\mathrm{Co}(\text { fur })_{2}(\mathrm{bpy})\right]$ & 175 & $6.5 \pm 0.5^{c}$ & $6.5 \pm 0.5^{c}$ & 32 \\
\hline$\left[\mathrm{Cu}(\text { fur })_{2}(\text { phpy })_{2}\left(\mathrm{H}_{2} \mathrm{O}\right)\right] \cdot$ phpy & 224 & $7.0 \pm 0.5$ & $7.0 \pm 0.5^{b}$ & 34 \\
\hline$\left[\mathrm{Ni}(\text { fur })_{2}(\right.$ phen $\left.)\left(\mathrm{H}_{2} \mathrm{O}\right)_{2}\right] \cdot \mathrm{H}_{2} \mathrm{O}$ & 249 & $6.7 \pm 0.3$ & $6.7 \pm 0.3^{b}$ & 35 \\
\hline$\left[\mathrm{Zn}_{2}(\text { fur })_{4}(\mathrm{py})_{2}\right]$ & 366 & $6.5 \pm 0.3^{c}$ & $6.5 \pm 0.3^{c}$ & 31 \\
\hline$\left[\mathrm{Cu}(\text { fur })_{2}\left(\mathrm{NH}_{2}-\mathrm{py}\right)_{2}\right]$ & 474 & $7.0 \pm 0.5$ & $7.0 \pm 0.5^{b}$ & 34 \\
\hline$\left[\mathrm{Ni}(\text { fur })_{2}(\mathrm{pz})_{4}\right] \cdot 2 \mathrm{MeCN}$ & 635 & $6.5 \pm 0.5$ & $0^{d}$ & 35 \\
\hline Hfur & 112 & $0^{d}$ & $0^{d}$ & \\
\hline Bpy & 78 & $0^{d}$ & $0^{d}$ & \\
\hline Neoc & 21 & $6.5 \pm 0.06^{b}$ & $0^{d}$ & \\
\hline Phen & 8 & $6.5 \pm 0.06^{b}$ & $0^{d}$ & \\
\hline Rif & 5 & 6.5 & 6.5 & \\
\hline INH & 100 & $7.0^{c}$ & $6.5^{c}$ & \\
\hline
\end{tabular}

${ }^{a}$ The diameter of the paper disk is $6 \mathrm{~mm} .{ }^{b}$ The zone of inhibition of culture growth does not overgrow within the specified time. ${ }^{c}$ The zone of inhibition of the growth of the bacterial culture, which initially appeared after several hours of growth, begins to overgrow over the entire surface of the zone. ${ }^{d} 0$ - no growth inhibition zone.

its methylated derivative, neoc, show a synergistic effect: they increase bioactivity by almost an order of magnitude ( $534 \mu \mathrm{g}$ per disk for 1 and 50 for 3 ). If the fur anion is replaced by $\mathrm{Ac}^{-}$, the biological activity of 4 towards $M$. smegmatis increases more than twofold ( $21 \mu \mathrm{g}$ per disk). If $\mathrm{Cu}^{2+}$ is used as a complexing agent, the biological activity increases to $12 \mu \mathrm{g}$ per disk for $\mathbf{5}$ (however, it remains lower than that of the previously obtained complex with 1,10-phenantroline $\left[\mathrm{Cu}(\text { fur })_{2}(\text { phen })^{31}\right)$ that shows the best result (Table 3 ). Thus, the $\mathrm{N}$-donor ligands in the complexes studied can be arranged in a series of biological efficiency (Scheme 2):

Moreover, analysis showed that the inhibition zone has the largest diameter in the case of $\mathbf{3}$ and does not overgrow during

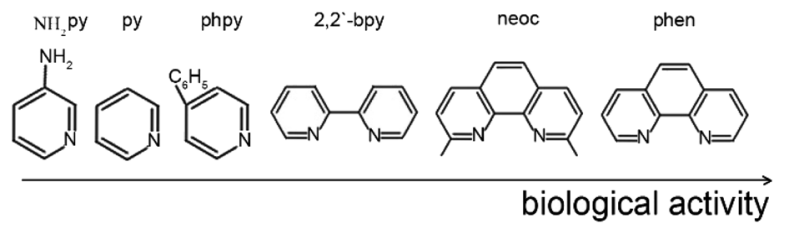

Scheme 2 A number of activities of $\mathrm{N}$-donor ligands in relation to $M$. smegmatis. the first day of exposure to the complex, as it was sometimes observed for a number of complexes (Table 3$).^{31-35}$

\section{Transcriptomic analysis $\left[\mathrm{Cu}(\text { fur })_{2}\right.$ (phen)] (RNA-seq)}

It is known that copper ions are an active cell death agent. Copper is an important cofactor for various enzymes, however free copper is very toxic to living cells. Copper can damage the structure and functions of enzymes by binding to S-, COO- and $\mathrm{NH}_{2}$-containing protein groups. In order to maintain the cellular metabolism at various concentrations of copper in the environment, bacteria have developed certain systems of copper homeostasis that mainly act as defense mechanisms. ${ }^{51,52}$ As with free-living bacteria, protection from copper is of critical importance for the virulence of pathogenic bacteria.

The fast-growing, non-pathogenic $M$. smegmatis species is a model organism for the tuberculosis originator Mycobacterium tuberculosis. Analysis of the transcriptome profiles of M. smegmatis $m c^{2} 155$ strain under the pressure of the most active copper complex $\left[\mathrm{Cu}(\text { fur })_{2}\right.$ (phen)] was carried out. ${ }^{31}$

RNA-seq identified 185 differentially expressed genes with parameters: False Discovery Rate (FDR $\leq 0.05 ; p$ value $\leq 0.05$; Fold change $\mathrm{FC} \geq 2 ; \log _{2} \mathrm{FC} \geq 1$ ): 84 downregulated genes and 101 upregulated genes. $118\left(-1.1>\log _{2} \mathrm{FC}>1.1\right)$ differentially 


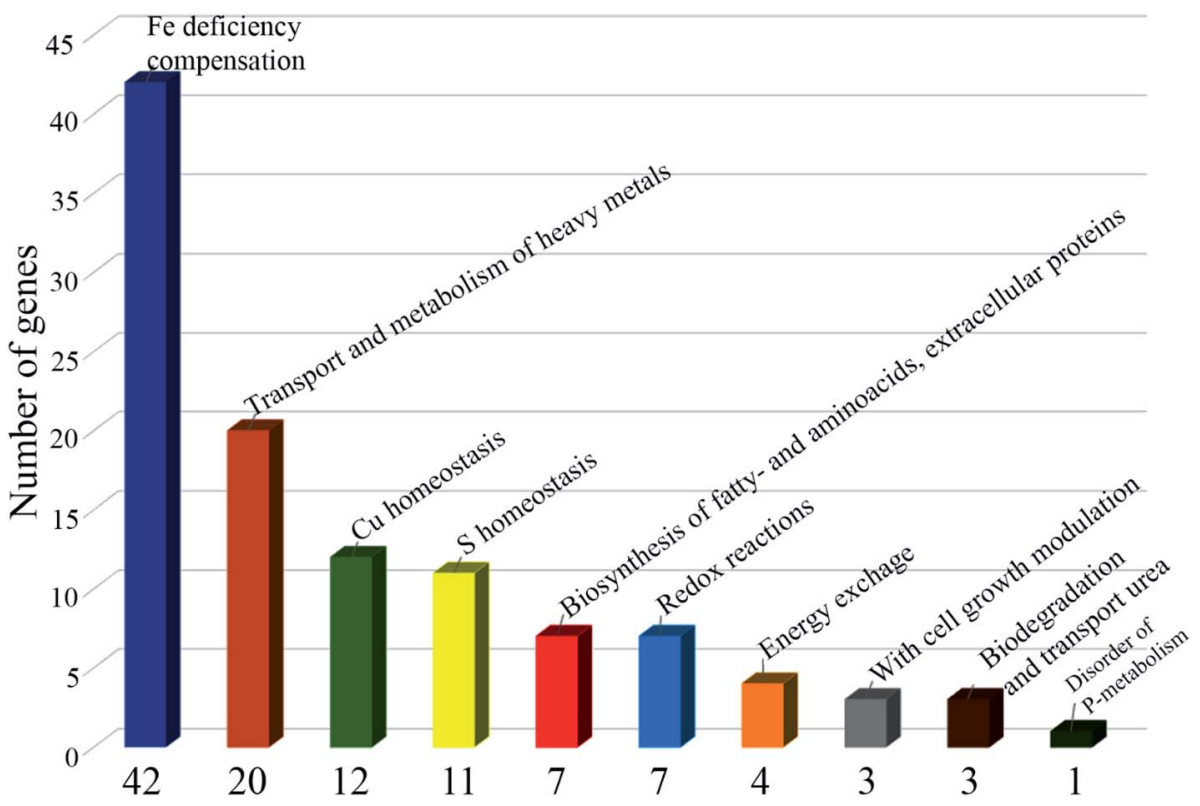

Scheme 3 Results of the RNA-seq.

expressed genes were selected for further analysis (Scheme 3). Of the differentially expressed genes, 12 are associated with copper homeostasis, 42 genes are associated with compensation for iron deficiency in the cell; 20 genes, with transport and metabolism of heavy metals, Mo, Ni, Zn, Co, Cd; 11 genes correspond to sulfur homeostasis; 4 genes are associated with energy metabolism; 7 genes are responsible for the biosynthesis of fatty acids, biosynthesis of the cell wall, biosynthesis of amino acids and extracellular proteins; 3 genes are associated with cell growth modulation, 3 genes for biodegradation and transport of urea; 1 gene is expressed when there is a lack of phosphate in the cell; there are 7 genes $\left(-1.9>\log _{2} \mathrm{FC}>1.7\right)$, functionally annotated, including those associated with redox processes in the cell; in addition, there are 8 genes of hypothetical proteins with unknown functions $\left(1.6>\log _{2} \mathrm{FC}>1.6\right)$.

Thus, under the pressure of the copper complex, the capture of copper by the cell stops and the outflux of copper from the cell increases. Moreover, violation of homeostasis of microelements vital for the mycobacterium occurs. Cellular processes are initiated to replenish strong iron starvation (iron is an important microelement for M. smegmatis and M. tuberculosis, as respiration processes are disrupted in case of its deficiency ${ }^{51}$ ). The absorption of $\mathrm{Ni}, \mathrm{Zn}, \mathrm{Cd}, \mathrm{Mo}$, As and the synthesis of cobalamin (Vit $\mathrm{B}_{12}$ ) decrease; the uptake of sulfur, its transport into the cell and assimilation are hindered; the transport of uric acid from the cell decreases, which may be a consequence of a slowdown in purine metabolism; the synthesis of extracellular proteins, amino/fatty acids and cell wall lipids is modified; hypoxia and phosphate deficiency indicators are activated.

\section{Conclusions}

Thus, complexes of $\mathrm{Zn}^{\mathrm{II}}$ and $\mathrm{Cu}^{\mathrm{II}}$ with fur ${ }^{-}$and $\mathrm{Ac}^{-}$anions incorporating molecules of $\mathrm{N}$-donor ligands (neocuproine and 3-aminopyridine) with polymeric (1) and molecular structures (2-5) have been synthesized. All the complexes are readily soluble in water and show stability according to NMR $\left({ }^{1} \mathrm{H}\right)$ data upon dissolution in DMSO solutions, as well as in glucose and $\mathrm{NaCl}$ solutions according to UV-vis results. The in vitro biological activity of the complexes against the model non-pathogenic strain M. smegmatis showed the lowest activity of polymeric complex 1. In this case, the transition from $\mathrm{Zn}^{2+}$ to $\mathrm{Cu}^{2+}$ cations indicate an increase in the activity of copper complexes. RNAseq for the most active copper complex $\left[\mathrm{Cu}(\mathrm{fur})_{2}(\right.$ phen $\left.)\right]$ made it possible to single out and identify 185 differentially expressed genes, one quarter of which are associated with iron deficiency compensation. The maximum changes in the expression level were recorded in the genes associated with the iron metabolism and transport, transport and metabolism of heavy metals, and copper homeostasis. Under the action of the copper complex, global changes occur in the metabolism and transport of iron and other metals, sulfur, amino acid (in particular arginine and alanine), the biosynthesis of lipids in M. smegmatis.

\section{Conflicts of interest}

The authors declare that they have no known competing financial interests or personal relationships that could have appeared to influence the work reported in this paper.

\section{Acknowledgements}

This work was financially supported by the Russian Science Foundation (project No. 20-13-00061). We are grateful to the User Facilities Center of Institute of General and Inorganic Chemistry of the Russian Academy of Sciences for physicochemical measurement (IR-spectroscopy, magnetic measurements, elemental and thermogravimetric analysis). DFT 
calculations were carried out using the computational facilities of Kazan National Research Technological University. X-ray diffraction data were collected with the financial support from the Ministry of Science and Higher Education of the Russian Federation using the equipment of Center for molecular composition studies of A.N. Nesmeyanov Institute of Organoelement Compounds is also gratefully acknowledged.

\section{Notes and references}

1 WHO Global tuberculosis report 2020, Geneva, World Health Organization.

2 A. Y. Louie and T. Meade, Proc. Natl. Acad. Sci. U. S. A., 1998, 95, 6663-6668.

3 S. Rojas, E. Quartapelle-Procopio, F. J. Carmona, M. A. Romero, J. A. R. Navarro and E. Barea, J. Mater. Chem. B, 2014, 2, 2473-2477.

4 K. H. Thompson and C. J. Orvig, J. Inorg. Biochem., 2006, 100, 1925-1935.

5 N. Bello-Vieda, H. Pastrana, M. Garavito, A. Ávila, A. Cells, A. Munos-Castro, S. Restrepo and J. J. Hurtado, Molecules, 2018, 23, 361.

6 L. Goodwin, J. Trop. Med. Hyg., 1995, 89, 339-341.

7 K. D. Mjos and C. Orvig, Chem. Rev., 2014, 114, 4540-4563.

8 B. Rosenberg, L. Vancamp and T. Krigas, Nature, 1965, 205, 698-699.

9 B. Rosenberg, L. Vancamp, J. E. Trosko and V. H. Mansour, Nature, 1969, 222, 385-386.

10 R. A. Alderden, M. D. Hall and T. W. J. Hambley, Chem. Educ., 2006, 83, 728.

11 S. J. Berners-Pric, L. Ronconi and P. J. Sadler, Prog. Nucl. Magn. Reson. Spectrosc., 2006, 49, 65-98.

12 M. J. Cleare and J. D. Hoeschele, Bioinorg. Chem., 1973, 2, 187-210.

13 M. J. Cleare and J. D. Hoeschele, Platinum Met. Rev., 1973, 17, 2-13.

14 S. Gibaud and G. Jaouen, Medicinal Organometallic Chemistry, 2010, 1-20.

15 M. Patra, G. Gasser and N. Metzler-Nolte, Dalton Trans., 2012, 41, 6350-6358.

16 E. S. Honsa, M. D. L. Johnson and J. W. Rosch, Front. Cell. Infect. Microbiol., 2013, 3, 92.

17 P. Nagababu, J. Naveena, L. Latha, P. Pallavi, S. Harish and S. Satyanarayana, Can. J. Microbiol., 2006, 52, 1247-1254.

18 K. Phopin, N. Sinthupoom, L. Treeratanapiboon, S. Kunwittaya, S. Prachayasittikul, S. Ruchirawat and V. Prachayasittikul, EXCLI J., 2016, 15, 144-152.

19 S. Rojas, T. Devic and P. Horcajadac, J. Mater. Chem. B, 2017, 5, 2560-2573.

20 J. R. Anacona, A. Bravo and M. E. Lopez, Lat. Am. J. Pharm., 2012, 31, 27-31.

21 K. Y. Djoko, M. M. Goytia, P. S. Donnelly, M. A. Schembri, W. M. Shafer and A. G. Mcewan, Antimicrob. Agents Chemother., 2015, 59, 6444-6485.

22 M. Tumer, H. Koksal and S. Serin, Transition Met. Chem., 1999, 24, 13-17.
23 F. Ijaz, N. Ahmad, I. Ahmad and A. ul Haq, J. Enzyme Inhib. Med. Chem., 2010, 25, 773-778.

24 O. Krasnovskaya, A. Naumov, D. Guk, P. Gorelkin, A. Erofeev, E. Beloglazkina and A. Majouga, Int. J. Mol. Sci., 2020, 21, 3965-4003.

25 A. H. Ngwane, R. D. Petersen, B. Baker, I. Wiid, H. Wong and R. K. Haynes, IUBMB Life, 2019, 71, 532-539.

26 D. Sriram, P. Yogeeswari, D. R. K. Vyas, P. Senthilkumar, P. Bhat and M. Srividya, Bioorg. Med. Chem. Lett., 2010, 20, 4313-4316.

27 T. Elsaman, M. Suliman and M. Mohamed, Bioorg. Chem., 2019, 88, 102969-103018.

28 P. Stüve, L. Minarrieta and H. Erdmann, Front. Immunol., 2018, 9, 495-517.

29 M. Krátk and J. Vinová, Curr. Med. Chem., 2012, 19, 61266137.

30 S. Melnic, D. Prodius, H. Stoeckli-Evans, S. Shova and C. Turta, Eur. J. Med. Chem., 2010, 45, 1465-1469.

31 I. A. Lutsenko, D. E. Baravikov, M. A. Kiskin, Y. V. Nelyubina, P. V. Primakov, O. B. Bekker, A. V. Khoroshilov, A. A. Sidorov and I. L. Eremenko, Russ. J. Coord. Chem., 2020, 46, 411-419.

32 I. A. Lutsenko, D. S. Yambulatov, M. A. Kiskin, Y. V. Nelyubina, P. V. Primakov, O. B. Bekker, A. A. Sidorov and I. L. Eremenko, Russ. J. Coord. Chem., 2020, 46, 787-796.

33 I. A. Lutsenko, D. S. Yambulatov, M. A. Kiskin, Y. V. Nelyubina, P. V. Primakov, O. B. Bekker, O. A. Levitskiy, T. V. Magdesieva, V. K. Imshennik, Yu. V. Maksimov, A. A. Sidorov and I. L. Eremenko, ChemistrySelect, 2020, 5, 11837-11842.

34 I. A. Lutsenko, M. A. Kiskin, K. A. Koshenskova, P. V. Primakov, A. V. Khoroshilov, O. B. Bekker and I. L. Eremenko, Russ. Chem. Bull., 2021, 70, 463-467.

35 M. A. Uvarova, I. A. Lutsenko, M. A. Kiskin, Y. V. Nelyubina, P. V. Primakov, K. A. Babeshkin, N. N. Efimov, A. Goloveshkin, M. A. Shmelev, A. V. Khoroshilov, E. M. Zueva, M. M. Petrova, O. B. Bekker and I. L. Eremenko, Polyhedron, 2021, 203, 115241-115248.

36 O. V. Dolomanov, L. J. Bourhis and R. J. Gildea, J. Appl. Crystallogr., 2009, 42, 339.

37 G. M. Sheldrick, Acta Crystallogr., Sect. C: Struct. Chem., 2015, 71, 3-8.

38 L. J. Bourhis, O. V. Dolomanov, R. J. Gildea, A. K. J. Howard and H. Puschmann, Acta Crystallogr., Sect. A: Found. Adv., 2015, 71, 59-75.

39 T. R. Rustad, D. M. Roberts, R. P. Liao and D. R. Sherman, Mycobacteria protocols, Humana Press, Totowa, NJ, 2010, pp. 13-22.

40 S. Andrews, FastQC: a quality control tool for high throughput sequence data, 2010, http:// www.bioinformatics.babraham.ac.uk/projects/fastqc.

41 A. M. Bolger, M. Lohse and B. Usadel, Bioinformatics, 2014, 30, 2114-2120.

42 D. Kim, J. M. Paggi, C. Park, C. Bennett and S. L. Salzberg, Nat. Biotechnol., 2019, 8, 907-915.

43 M. D. Robinson, D. J. McCarthy and G. K. Smyth, Bioinformatics, 2010, 26, 139-140. 
44 G. Smith, E. O'Reilly, C. H. L. Kennard and T. C. W. Mak, Inorg. Chem., 1985, 24, 2321-2324.

45 B. Paluchowska, J. K. Maurin and J. Leciejewicz, J. Coord. Chem., 2006, 52, 253-264.

46 A. Tarushi, X. Totta, C. P. Raptopoulou, V. Psycharis, G. Psomas and D. P. Kessissoglou, Dalton Trans., 2012, 41, 7082.

47 D. Özge, K. Dursun, A. Şahin, O. Şahin and Z. Sibel, J. Therm. Anal. Calorim., 2017, 128, 1373-1383.

48 J. Toigo, G. Farias, C. A. M. Salla, L. G. T. A. Duarte, A. J. Bortoluzzi, T. D. Zambon Atvars and I. H. Bechtold, Eur. J. Inorg. Chem., 2021, 31, 3177-3184.

49 Y.-T. Liu, X. Yin, X.-Y. Lai and X. Wang, Dyes Pigm., 2020, 108244-108261.

50 R. Brahma and J. B. Baruah, ACS Omega, 2020, 136-147.

51 G. Raymoni and H. Abu Alijazi, Synthesis, Appl. Organomet. Chem., 2018, 4680-4696.
52 L. Pazderski, T. Pawlak, J. Sitkowski, L. Kozerski and E. Szłyk, Magn. Reson. Chem., 2010, 48, 2600-26008.

53 P. Timmerman, J.-L. Weidmann, K. A. Jolliffe, L. J. Prins, D. N. Reinhoudt, S. Shinkai, L. Frish and Y. Cohen, J. Chem. Soc., Perkin Trans. 1, 2000, 2, 2077-2089.

54 S. Ramon-García, C. Ng, H. Anderson, J. D. Chao, X. Zheng, T. Pfeifer, Y. Av-Gay, M. Roberge and C. J. Thompson, Antimicrob. Agents Chemother., 2011, 8, 3861-3869.

55 O. B. Bekker, D. N. Sokolov, O. A. Luzina, N. I. Komarova, Y. V. Gatilov, S. N. Andreevskaya, T. G. Smirnova, D. A. Maslov, L. N. Chernousova, N. F. Salakhutdinov and V. N. Danilenko, Med. Chem. Res., 2015, 24, 2926-2938.

56 A. Srivastava, Resonance, 2009, 14, 754-760.

57 I. A. Khodov, G. A. Alper, G. M. Mamardashvili and N. Zh. Mamardashvili, J. Mol. Struct., 2015, 1099, 174. 58 J. Youatt, Austral. J. Exp. Biol., 1962, 40, 201-205. 59 G. M. Rodriguez, Trends Microbiol., 2006, 14, 320-327. 